\title{
Employee Management on Large Ranches
}

\author{
By Ryan D. Rhoades, J. J. Livsey, Kim C. McCuistion, and Clay P. Mathis
}

\section{On the Ground}

- Managing people is a vital component of managing a large ranch. Employee management practices have an effect on turnover in any organization, and our study specifically examined management practices on ranches.

- Our study describes the state of employee management on large ranches and provides useful and practical information that may help ranch managers build their personnel management skills.

- Managers could potentially enhance employee performance by reviewing their operations management procedures and incentive structures and adjusting them as needed.

Keywords: ranch employee, ranch management, turnover, incentives.

Rangelands 35(2):2-11

doi: 10.2111/RANGELANDS-D-12-00076.1

(C) 2013 The Society for Range Management

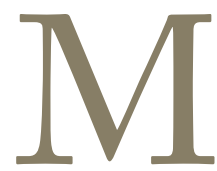

anaging a large ranch means not only managing land, livestock, and natural resources but managing human resources as well. Knowledge of ranch employee management is as important for the success of larger ranches as understanding cattle markets and production. However, while there are numerous books and research reports on the subject of employee management, including management of employees in agriculture, there has never been a study of employee management practices on ranches.

How do managers measure and incentivize ranch employees? The tasks that ranch employees must accomplish can be highly varied in skill required, level of complexity, and level of responsibility. Accurately and fairly measuring each employee's performance can be difficult. Commonly used measurements for evaluation range from production metrics to both quantitative and qualitative assessments of people-management skills. Measuring performance based on achievement of outcomes can be an effective way to evaluate and reward employees. However, this approach can be an unfair method of evaluation in complex, unpredictable environments such as ranching, where good long-term decisions often require short-term financial and production sacrifices. Additionally, motivating employees to improve performance typically means using incentives to change behavior. There are a number of techniques used to motivate ranch employees. The challenge is that not all employees are motivated by the same incentives. Correctly incentivizing employees is an important aspect of management to improve ranch performance.

In an industry that is shrinking in both number of cattle and people in the business, it is increasingly difficult and expensive to find, develop, and retain qualified ranch employees. Retaining employees depends on work satisfaction and success in any organization. Conversely, employee turnover can be costly as numerous expenses are incurred during the hiring process and as a result of lost productivity. Turnover can result from a multitude of factors, some beyond the control of managers; however, ranch managers can positively or negatively impact satisfaction and success through their use of some key employee management practices. The objectives of our study were to 1) qualify and measure ranch employee and manager perceptions of employee management practices, 2) identify methods used to incentivize ranch employee performance, and 3) determine the relationship between employee management practices and key performance metrics.

\section{Surveying Ranch Employees and Managers}

For our study we initially considered the National Cattlemen's Beef Association 2010 Top 25 Cow/Calf Operations list. The list was expanded to include other large ranches not on the National Cattlemen list to obtain 14 ranches in the study. Ranches with at least 4,000 commercial cows were identified and included in the data set. Ranches in the data set range in size from 4,000 to 44,000 beef cows, and from seven to 100 full-time employees. Ranches in Texas, Missouri, Florida, 
Montana, Wyoming, Hawaii, Colorado, New Mexico, and Oregon were represented. Ownership structures represented in the data set included corporate, absentee family, and trust. All ranches were managed by nonfamily employees.

We created two surveys to capture employee and general manager perspectives on employee management. We conducted a pilot test of the survey instruments among key stakeholders to solicit feedback and determine if the instructions and meaning of each question were clear before the final survey was delivered to all 14 participating ranches. The final survey was delivered by mail and e-mail.

The ranch employee survey was completed by 190 fulltime ranch employees over the age of 18 . This survey consisted of eight qualitative questions and 10 demographic questions. Qualitative questions included importance and perception ratings of 14 employee management factors in terms of impact on employee satisfaction and success. Importance was rated on a four-point scale of unimportant (1), slightly unimportant (2), slightly important (3), and important (4). Perception was rated on a four-point scale of strongly disagree (1), disagree (2), agree (3), and strongly agree (4). Questions pertaining to employee engagement and incentive methods were also included. Ranch employees had the option to complete the survey online (six online surveys completed) or on paper (184 paper surveys).

The general manager survey was completed by 14 ranch general managers of a single ranch or system of ranches, depending upon business structure. The feneral manager survey consisted of 10 qualitative questions and four ranch and personal experience demographic questions. Like the employees surveyed, general managers were asked to rate the importance and perception, in terms of employee satisfaction and success, of 14 employee management factors. Other questions asked of general managers focused on evaluation metrics, incentive methods, turnover rate, and labor cost per cow. Managers had the option to complete the survey online or on paper (seven of each were completed).

\section{Key Metrics and Analysis}

The following statement was used to clarify the meaning of "engagement" for the purposes of the survey: "An engaged employee is fully involved in and enthusiastic about his or her work, and therefore acts in a way that furthers their organization's interest." Employees were asked to describe their own level of engagement based on a four-point scale of low (1), somewhat low (2), somewhat high (3), and high (4). General managers were asked to describe the average level of employee engagement on their ranch using the same four-point scale.

"Turnover rate" was defined as the number of full-time employees who left the ranch (voluntarily or involuntarily) in a given year divided by the total number of full-time employees who worked on the ranch in that year. Five-year averages were collected. Ranches were classified into seven with above median (high) and seven with below median turnover (low).
"Labor cost per cow" was calculated by dividing annual labor expenses by number of beef cows on the ranch. General managers were instructed to include employee benefits in labor expenses.

Numerical importance and perception ratings were used to calculate discrepancy scores, or gaps, for all management factors. A discrepancy score is the difference between importance rating and perception rating and represents the difference between desired and actual conditions. Discrepancies were calculated using the Borich needs assessment model. ${ }^{1}$

An SPSS statistics program ${ }^{2}$ was used to identify correlations, means, and standard deviations for each survey question and key metric. Pearson $\rho$ correlations were used to measure relationships between numerical importance ratings, perception ratings, and discrepancies. Pearson $\rho$ was also employed to evaluate data on the relationship of survey responses to engagement, turnover rate, and labor cost per cow.

\section{Perceptions of Ranch Employees and Managers \\ Demographics}

The data set included responses from 190 employees, which represents $31 \%$ of the total full-time employees working on the 14 large ranches. Twenty-seven percent of employees surveyed were classified as managers of cowboys and $73 \%$ as cowboys. The majority of employees, nearly $75 \%$, were between the ages of 30 and 60 . Additionally, more than $75 \%$ had 10 years or more of ranching experience. Forty-seven percent of employees had a high school degree, but less than $20 \%$ had achieved a college degree. In addition, more than $65 \%$ of employees received an annual salary of between $\$ 20,000$ and $\$ 30,000$, and less than $10 \%$ made more than $\$ 50,000$ per year.

On average, general managers had 20 years of experience at the ranch they were currently managing, 23 years of total ranch management experience, and 36 years of total ranching experience. In total, the 14 ranches represented 195,800 head of beef cows (average $=13,053$ ) and 620 full-time employees (average $=41)$.

\section{Key Metrics}

The percentage of employees who classified themselves in each of the four levels of engagement is presented in Figure 1. The average employee engagement was 3.27 , while the average of general managers' estimate of employee engagement on their ranch was 3.00. The simple act of communicating with employees about what engagement means could prompt employees to reassess their own engagement level and work to become more engaged, if general managers state that engagement is a desirable employee characteristic. The median employee turnover rate was $11.7 \%$, ranging from $2.9 \%$ to $34.4 \%$. Turnover on ranches can be very expensive. The cost of employee turnover is directly related to the cost of employee replacement, which is estimated to range from $50 \%$ to $150 \%$ of annual salary as numerous expenses are incurred 


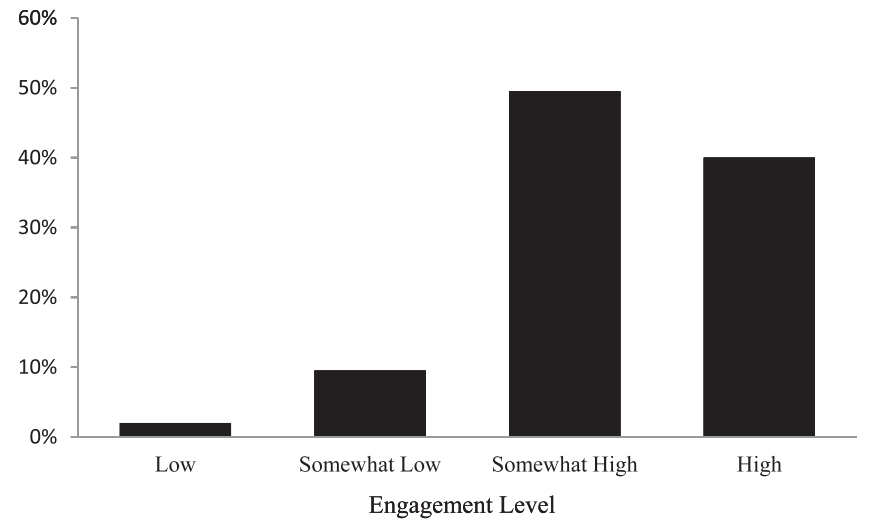

Figure 1. Percentage of employees self-classified in each category of employee engagement.

during the hiring process and as a result of lost productivity. ${ }^{3}$ The 5-year average labor cost per cow was $\$ 93.67$, ranging from $\$ 15.56$ to $\$ 161.55$. The number of employees per cow will increase or decrease labor costs per cow. Labor requirements will vary greatly on ranches depending upon the scope of the operation and management intensity. In a recent beef cow-calf enterprise cost-return projection, average labor cost per exposed cow was estimated at $\$ 79.65$ using 5.9 hours of labor per cow. ${ }^{4}$

\section{Employee Management Factors}

Average general manager and employee importance and perception ratings and gaps for each of the 14 employee management factors are listed in Table 1. Importance ratings were similar between employees and general managers. The areas in which general managers and employees differed the most were "knowing and understanding the mission statement" (3.07 general managers vs. 3.71 employees), "on-ranch work opportunities for family members" (2.67 general managers vs. 3.25 employees), "feeling that the manager(s) take personal interest in them" (3.80 general managers vs. 3.47 employees), and "recognition from a manager(s) for good work" (3.93 general managers vs. 3.61 employees).

Although "on-ranch work opportunities for family members" ranks low in importance for both groups, the large difference between them is important to note. On a ranch, family life is often tied to daily work. If an employee's family can enjoy the ranch, that employee may become more engaged and motivated.

Interestingly, general managers indicated a higher importance rating for the soft factors "feeling managers take a personal interest" and "recognition from managers." Conversely, previous research indicates that personal interest and recognition are very important factors for employee satisfaction and success. ${ }^{5}$ In our study, this is likely a result of the cowboy culture being somewhat stoic with a high value on independence.

The areas in which general managers and employees differed the most in average perception ratings were "new employee training" (2.93 general managers vs. 2.36 employees), "recognition from a manager(s) for good work" (3.53 general managers vs. 3.10 employees), "feeling that the manager(s) take personal interest in them" (3.27 general managers vs. 2.95 employees), and "knowing and understanding the mission statement" ( 2.73 general managers vs. 3.02 employees). A lower employee perception rating for "new employee training" suggests that although the average general manager agrees that new employees go through new employee training, employees do not generally agree that it prepared them for their jobs. Research suggests that $40 \%$ of new hires depart within their first two 2 years because of integration difficulties. ${ }^{3} \mathrm{~A}$ well-executed new employee training program is critical to clarify expectations and job performance goals, and to communicate a link between the employee's job and the organization. ${ }^{3}$

A higher gap ranking means there is a greater difference between importance and perception for that factor. A greater difference suggests there is a greater opportunity for improvement within that factor, because participants believe it is important but underdelivered. The three areas in which general managers and employees differed the most in gap rankings were "challenging and interesting work" (first for general managers [tie] vs. 13th for employees), "feeling that a manager(s) takes personal interest in them" (third for general managers [tie] vs. 11th for employees), and "understanding why management decisions are made" (11th for general managers [tie] vs. third for employees). Interestingly, there was a larger gap among general managers for "challenging and interesting work," primarily due to the difference in perception. General managers may perceive the need to continuously provide employees with new and challenging work, whereas employees may have made a preemployment decision that the job is adequately challenging and interesting. On the other hand, there was a larger gap among employees for "understanding why management decisions are made," which is likely a result of managers assuming employees already understand and that conclusions are obvious. It is common for busy managers to focus on outcomes rather than the process of making decisions, which can lead to confusion and resistance to change. Trust is an important part of employee management and employees are more likely to buy in to management decisions if they are either involved in the process or told the rationale behind why the decision has been made.

Overall, general managers deemed it less important that employees understand the mission statement than employees did, but general managers also perceived that employees understood the mission statement less than employees perceived they did. Prioritizing efforts to ensure employees, no matter their level, know and understand the ranch's mission statement could be a simple way to help employees understand the overarching purpose of their job and a way to increase retention.

\section{Incentives}

Figure 2 compares rankings of the general managers' and employees' most motivating factors. General managers were 
Table 1. Gaps with rankings for 14 employee management factors by general managers and employee groups

\begin{tabular}{|c|c|c|c|c|c|c|c|c|c|c|c|c|}
\hline \multirow{2}{*}{$\begin{array}{l}\text { Employee } \\
\text { management factor }\end{array}$} & \multicolumn{6}{|c|}{ General managers* } & \multicolumn{6}{|c|}{ Employeest } \\
\hline & Importance & SD & Perception & SD & Gap & Rank & Importance & SD & Perception & SD & Gap & Rank \\
\hline $\begin{array}{l}\text { Knowing and understanding } \\
\text { the mission statement }\end{array}$ & 3.07 & 0.65 & 2.73 & 0.59 & 0.34 & 11 & 3.71 & 0.45 & 3.02 & 0.71 & 0.69 & 6 \\
\hline $\begin{array}{l}\text { Clearly understanding perfor- } \\
\text { mance expectations }\end{array}$ & 3.93 & 0.25 & 3.27 & 0.59 & 0.66 & $1 \mathrm{~T} \neq$ & 3.84 & 0.41 & 3.11 & 0.71 & 0.73 & 5 \\
\hline $\begin{array}{l}\text { Feeling that criteria used to } \\
\text { evaluate them accurately rep- } \\
\text { resents their job performance }\end{array}$ & 3.47 & 0.73 & 3.07 & 0.59 & 0.40 & $9 \mathrm{~T}$ & 3.65 & 0.59 & 3.07 & 0.71 & 0.58 & 9 \\
\hline $\begin{array}{l}\text { Having the tools and informa- } \\
\text { tion necessary for the job }\end{array}$ & 3.80 & 0.56 & 3.27 & 0.59 & 0.53 & ЗТ & 3.93 & 0.25 & 3.09 & 0.65 & 0.84 & 2 \\
\hline $\begin{array}{l}\text { Challenging and interesting } \\
\text { work }\end{array}$ & 3.73 & 0.45 & 3.07 & 0.45 & 0.66 & $1 \mathrm{~T}$ & 3.77 & 0.41 & 3.30 & 0.59 & 0.47 & 13 \\
\hline $\begin{array}{l}\text { Recognition from a } \\
\text { manager(s) for good work }\end{array}$ & 3.93 & 0.25 & 3.53 & 0.51 & 0.40 & 9T & 3.61 & 0.59 & 3.10 & 0.63 & 0.51 & 12 \\
\hline $\begin{array}{l}\text { Feeling that a manager(s) } \\
\text { takes personal interest in } \\
\text { them }\end{array}$ & 3.80 & 0.41 & 3.27 & 0.59 & 0.53 & 3T & 3.47 & 0.71 & 2.95 & 0.71 & 0.52 & 11 \\
\hline $\begin{array}{l}\text { Understanding why manage- } \\
\text { ment decisions are made }\end{array}$ & 3.40 & 0.91 & 3.07 & 0.71 & 0.33 & 12 & 3.61 & 0.71 & 2.81 & 0.79 & 0.80 & 3 \\
\hline $\begin{array}{l}\text { Opportunities for job-related } \\
\text { training and personal devel- } \\
\text { opment opportunities }\end{array}$ & 3.33 & 0.91 & 2.87 & 0.51 & 0.46 & 8 & 3.53 & 0.65 & 2.94 & 0.71 & 0.59 & 8 \\
\hline $\begin{array}{l}\text { Meaningful, timely, and con- } \\
\text { structive feedback }\end{array}$ & 3.60 & 0.63 & 3.07 & 0.71 & 0.53 & 3T & 3.67 & 0.59 & 2.89 & 0.71 & 0.78 & 4 \\
\hline $\begin{array}{l}\text { Feeling that managers } \\
\text { welcome their opinions and } \\
\text { suggestions }\end{array}$ & 3.80 & 0.41 & 3.33 & 0.48 & 0.47 & $6 \mathrm{~T}$ & 3.71 & 0.56 & 3.03 & 0.68 & 0.68 & 7 \\
\hline $\begin{array}{l}\text { On-ranch work opportunities } \\
\text { for family members }\end{array}$ & 2.67 & 1.04 & 2.67 & 0.71 & 0.00 & 14 & 3.25 & 0.91 & 2.69 & 0.91 & 0.56 & 10 \\
\hline $\begin{array}{l}\text { On-ranch recreational oppor- } \\
\text { tunities for family members }\end{array}$ & 3.00 & 0.65 & 2.93 & 0.59 & 0.07 & 13 & 3.29 & 0.91 & 2.99 & 0.71 & 0.30 & 14 \\
\hline New employee training & 3.40 & 0.91 & 2.93 & 0.59 & 0.47 & $6 \mathrm{~T}$ & 3.43 & 0.79 & 2.36 & 0.79 & 1.07 & 1 \\
\hline
\end{tabular}


asked to identify from the list of employee incentives only the top five incentives they believe were most motivating to their ranch employees. Motivation involves encouraging employees to achievement that will support the organization's desired goals. The top three incentives most frequently selected as a motivating factor were "salary increase" (93\%), "opportunities for advancement" (80\%), and "increased responsibility and decision making power" (73\%). Modern businesses are largely structured around extrinsic motivators, such as money. ${ }^{6}$ Extrinsic motivators work well for simple tasks with a clear goal and a narrow focus.

Using the same list of incentives, employees were asked to identify only the top five factors that were most motivating to them. The top three incentives most frequently selected were "bonuses based on personal achievement" (83\%), "salary increase" (78\%), and "increased responsibility and decision making power" (60\%). Similarly, in a study involving members of a farmers' cooperative, researchers found that a majority of workers were most likely to be motivated by incentives that allow them to achieve a higher level of competency. ${ }^{7}$ In addition, autonomy or increased responsibility and the freedom to make decisions are much more effective at driving results when work is complex, ${ }^{6}$ such as ranching. The value of these incentives is important for managers to understand because the ability to lead depends on understanding what will encourage employees to perform.

In our study, the top five employee incentives were ranked similarly by both groups. General managers in our study likely moved up the ranks so they perhaps have a better understanding of factors that motivate ranch employees that report to them. Likewise, in ranching a close relationship between managers and employees exists in order to retain employees because salaries are generally low.

\section{Ranches with Low or High Turnover}

General managers. Table 2 lists general managers' importance and perception ratings along with gaps for each of the 14 employee management factors, grouped into either low or high turnover. This ranking, which quantifies the difference between what the general managers find to be important and how they perceive those factors to actually be on the ranch, helps identify factors that may play an important part in employee turnover.

Notable differences between low-turnover and high-turnover ranches in general manager importance ratings include "understanding why management decisions are made" (3.71 low vs. 3.00 high), "opportunities for job-related training and personal development" (3.14 low vs. 3.57 high), "knowing and understanding the mission statement" (2.86 low vs. 3.14 high), and "new employee training" (3.29 low vs. 3.57 high).

The average perception rating for all factors was 3.18 and 2.92 for low and high turnover ranches, respectively. Clearly, general managers at high-turnover ranches recognize there is room for improvement. The only factor for which general managers on high-turnover ranches had a higher perception

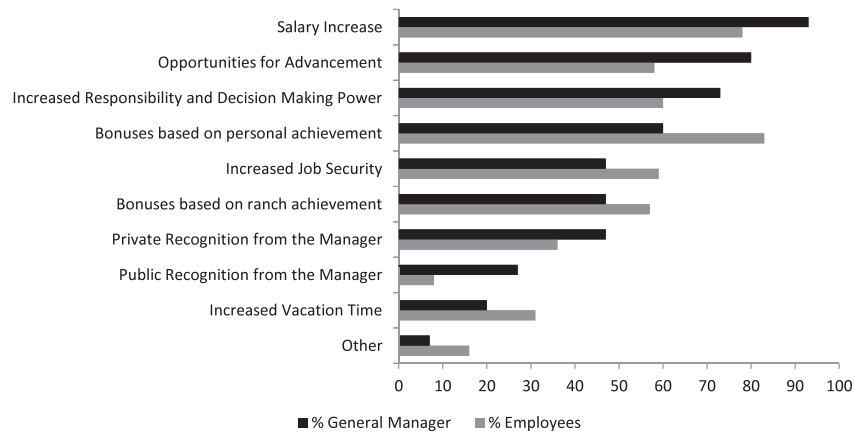

Figure 2. Ranking of ranch employee motivation factors based on highest percentage of responses from general managers. Percentage represents the number of respondents that selected incentive divided by the total number of respondents for general managers $(n=14)$ and employees $(n=96)$.

rating (3.14 high vs. 2.71 low) was "on-ranch recreational opportunities for family members."

The average gap for all factors was 0.30 and 0.54 for lowand high-turnover ranches, respectively. Areas for improvement for general managers on low-turnover ranches were greatest for "clearly understanding performance expectations," "having the tools and information necessary for the job," "challenging and interesting work," and "understanding why management decisions are made." Gaps for general managers on high-turnover ranches were greatest for "clearly understanding performance expectations," "opportunities for job-related training and personal development," and "new employee training." "Clearly understanding performance expectations" was rated the highest factor for importance by all general managers making this factor the area in which the greatest improvement can be generated. To perform well, employees need to understand what is expected of them. From a general manager's perspective, an employee's understanding of performance expectations are critical because they serve as the basis for evaluating employee performance. These expectations then provide the manager with a foundation for communicating and providing feedback about expected vs. actual performance.

Overall, providing employees with development and training opportunities were among the smallest gaps for general managers on low-turnover ranches. The difference between importance and perceived utilization for "new employee training" at ranches with high turnover was much higher than the gap at low-turnover ranches ( 0.86 high vs. 0.14 low). However, general managers at high-turnover ranches recognize that training employees, both when they first start and throughout their employment, is an area that needs improvement. It is unsurprising that the gap for development opportunities was higher on ranches with high turnover. If an employee feels they do not have the opportunity to grow, they are less likely to be engaged. Engagement has been highly correlated to employee turnover in other industries. ${ }^{8}$

Employees. Table 3 lists employees' importance and perception ratings along with gaps for the 14 employee man- 
Table 2. General manager gaps with rankings for 14 employee management factors grouped by employment on ranches with low or high turnover*

\begin{tabular}{|c|c|c|c|c|c|c|c|c|c|c|c|c|}
\hline \multirow{2}{*}{$\begin{array}{l}\text { Employee management } \\
\text { factor }\end{array}$} & \multicolumn{6}{|c|}{ General managers on ranches with low turnovert } & \multicolumn{6}{|c|}{ General managers on ranches with high turnover‡ } \\
\hline & Importance & SD & Perception & SD & Gap & Rank & Importance & SD & Perception & SD & Gap & Rank \\
\hline $\begin{array}{l}\text { Knowing and understand- } \\
\text { ing the mission statement }\end{array}$ & 2.86 & 0.89 & 2.86 & 0.69 & 0.00 & $13 \mathrm{~T}$ & 3.14 & 0.39 & 2.57 & 0.51 & 0.57 & $7 \mathrm{~T}$ \\
\hline $\begin{array}{l}\text { Clearly understanding per- } \\
\text { formance expectations }\end{array}$ & 4.00 & 0.00 & 3.43 & 0.51 & 0.57 & $1 \mathrm{~T}$ & 3.86 & 0.41 & 3.00 & 0.63 & 0.86 & $1 \mathrm{~T}$ \\
\hline $\begin{array}{l}\text { Feeling that criteria used to } \\
\text { evaluate them accurately rep- } \\
\text { resents their job performance }\end{array}$ & 3.43 & 0.81 & 3.29 & 0.79 & 0.14 & $10 \mathrm{~T}$ & 3.57 & 0.81 & 3.00 & 0.05 & 0.57 & $7 \mathrm{~T}$ \\
\hline $\begin{array}{l}\text { Having the tools and } \\
\text { information necessary for } \\
\text { the job }\end{array}$ & 3.86 & 0.39 & 3.29 & 0.51 & 0.57 & $1 \mathrm{~T}$ & 3.71 & 0.81 & 3.14 & 0.41 & 0.57 & $7 \mathrm{~T}$ \\
\hline $\begin{array}{l}\text { Challenging and interesting } \\
\text { work }\end{array}$ & 3.71 & 0.51 & 3.14 & 0.39 & 0.57 & $1 \mathrm{~T}$ & 3.71 & 0.48 & 3.00 & 0.59 & 0.71 & $4 \mathrm{~T}$ \\
\hline $\begin{array}{l}\text { Recognition from a } \\
\text { manager(s) for good work }\end{array}$ & 3.86 & 0.39 & 3.57 & 0.51 & 0.29 & $8 \mathrm{~T}$ & 4.00 & 0.00 & 3.43 & 0.51 & 0.57 & $7 \mathrm{~T}$ \\
\hline $\begin{array}{l}\text { Feeling that a manager(s) } \\
\text { takes personal interest in } \\
\text { them }\end{array}$ & 3.86 & 0.39 & 3.43 & 0.51 & 0.43 & 5T & 3.71 & 0.51 & 3.00 & 0.59 & 0.71 & $4 \mathrm{~T}$ \\
\hline $\begin{array}{l}\text { Understanding why manage- } \\
\text { ment decisions are made }\end{array}$ & 3.71 & 0.51 & 3.14 & 0.71 & 0.57 & $1 \mathrm{~T}$ & 3.00 & 1.22 & 2.86 & 0.71 & 0.14 & $13 \mathrm{~T}$ \\
\hline $\begin{array}{l}\text { Opportunities for job-relat- } \\
\text { ed training and personal } \\
\text { development opportunities }\end{array}$ & 3.14 & 1.23 & 3.00 & 0.59 & 0.14 & $10 \mathrm{~T}$ & 3.57 & 0.49 & 2.71 & 0.51 & 0.86 & $1 \mathrm{~T}$ \\
\hline $\begin{array}{l}\text { Meaningful, timely, and } \\
\text { constructive feedback }\end{array}$ & 3.71 & 0.49 & 3.29 & 0.81 & 0.43 & 5T & 3.57 & 0.79 & 2.86 & 0.71 & 0.71 & $4 \mathrm{~T}$ \\
\hline $\begin{array}{l}\text { Feeling that managers } \\
\text { welcome their opinions and } \\
\text { suggestions }\end{array}$ & 3.71 & 0.51 & 3.29 & 0.51 & 0.43 & $5 \mathrm{~T}$ & 3.86 & 0.41 & 3.29 & 0.49 & 0.57 & $7 \mathrm{~T}$ \\
\hline $\begin{array}{l}\text { On-ranch work opportuni- } \\
\text { ties for family members }\end{array}$ & 2.71 & 1.11 & 2.86 & 0.69 & 0.14 & 15 & 2.57 & 1.09 & 2.43 & 0.79 & 0.14 & $13 \mathrm{~T}$ \\
\hline $\begin{array}{l}\text { On-ranch recreational oppor- } \\
\text { tunities for family members }\end{array}$ & 3.00 & 0.59 & 2.71 & 0.51 & 0.29 & $8 T$ & 3.00 & 0.81 & 3.14 & 0.71 & 0.14 & 15 \\
\hline New employee training & 3.29 & 1.11 & 3.14 & 0.71 & 0.14 & $10 \mathrm{~T}$ & 3.57 & 0.81 & 2.71 & 0.81 & 0.86 & $1 \mathrm{~T}$ \\
\hline
\end{tabular}


Table 3. Employee gaps with rankings for 14 employee management factors grouped by employment on ranches with low or high turnover*

\begin{tabular}{|c|c|c|c|c|c|c|c|c|c|c|c|c|}
\hline \multirow{2}{*}{$\begin{array}{l}\text { Employee management } \\
\text { factor }\end{array}$} & \multicolumn{6}{|c|}{ Employees on ranches with low turnovert } & \multicolumn{6}{|c|}{ Employees on ranches with high turnover $¥$} \\
\hline & Importance & SD & Perception & SD & Gap & Rank & Importance & SD & Perception & SD & Gap & Rank \\
\hline $\begin{array}{l}\text { Knowing and understanding the } \\
\text { mission statement }\end{array}$ & 3.73 & 0.39 & 2.99 & 0.78 & 0.75 & 7 & 3.66 & 0.59 & 2.96 & 0.69 & 0.70 & 3 \\
\hline $\begin{array}{l}\text { Clearly understanding perfor- } \\
\text { mance expectations }\end{array}$ & 3.83 & 0.39 & 2.95 & 0.81 & 0.88 & 5 & 3.84 & 0.41 & 3.15 & 0.71 & 0.70 & 5 \\
\hline $\begin{array}{l}\text { Feeling that criteria used to } \\
\text { evaluate them accurately repre- } \\
\text { sents their job performance }\end{array}$ & 3.65 & 0.61 & 2.93 & 0.73 & 0.72 & 8 & 3.62 & 0.59 & 3.11 & 0.61 & 0.51 & 12 \\
\hline $\begin{array}{l}\text { Having the tools and informa- } \\
\text { tion necessary for the job }\end{array}$ & 3.92 & 0.31 & 2.97 & 0.69 & 0.95 & 3 & 3.94 & 0.22 & 3.11 & 0.71 & 0.83 & 2 \\
\hline $\begin{array}{l}\text { Challenging and interesting } \\
\text { work }\end{array}$ & 3.74 & 0.43 & 3.19 & 0.61 & 0.56 & 13 & 3.76 & 0.51 & 3.37 & 0.61 & 0.40 & 13 \\
\hline $\begin{array}{l}\text { Recognition from a manager(s) } \\
\text { for good work }\end{array}$ & 3.52 & 0.72 & 2.93 & 0.61 & 0.59 & 11 & 3.65 & 0.61 & 3.14 & 0.49 & 0.51 & 9 \\
\hline $\begin{array}{l}\text { Feeling that a manager(s) takes } \\
\text { personal interest in them }\end{array}$ & 3.39 & 0.79 & 2.79 & 0.71 & 0.60 & 12 & 3.49 & 0.72 & 2.97 & 0.61 & 0.52 & 7 \\
\hline $\begin{array}{l}\text { Understanding why manage- } \\
\text { ment decisions are made }\end{array}$ & 3.65 & 0.61 & 2.60 & 0.89 & 1.05 & 2 & 3.59 & 0.71 & 2.87 & 0.69 & 0.72 & 6 \\
\hline $\begin{array}{l}\text { Opportunities for job-related } \\
\text { training and personal develop- } \\
\text { ment opportunities }\end{array}$ & 3.47 & 0.81 & 2.85 & 0.81 & 0.62 & 10 & 3.57 & 0.69 & 2.97 & 0.71 & 0.60 & 8 \\
\hline $\begin{array}{l}\text { Meaningful, timely, and con- } \\
\text { structive feedback }\end{array}$ & 3.65 & 0.59 & 2.64 & 0.81 & 1.01 & 4 & 3.65 & 0.62 & 2.98 & 0.51 & 0.67 & 4 \\
\hline $\begin{array}{l}\text { Feeling that managers welcome } \\
\text { their opinions and suggestions }\end{array}$ & 3.72 & 0.61 & 2.80 & 0.81 & 0.92 & 6 & 3.68 & 0.59 & 3.13 & 0.69 & 0.55 & 10 \\
\hline $\begin{array}{l}\text { On-ranch work opportunities for } \\
\text { family members }\end{array}$ & 3.11 & 1.03 & 2.46 & 0.81 & 0.65 & 9 & 3.31 & 0.91 & 2.74 & 0.81 & 0.57 & 11 \\
\hline $\begin{array}{l}\text { On-ranch recreational opportu- } \\
\text { nities for family members }\end{array}$ & 3.23 & 1.01 & 2.94 & 0.69 & 0.29 & 14 & 3.36 & 0.81 & 2.98 & 0.71 & 0.38 & 14 \\
\hline New employee training & 3.53 & 0.79 & 2.39 & 0.81 & 1.14 & 1 & 3.39 & 0.91 & 2.30 & 0.81 & 1.09 & 1 \\
\hline
\end{tabular}


Table 4. Survey factors statistically significantly correlated to employee engagement

\begin{tabular}{|l|l|l|}
\hline Employee survey factor & $\mathbf{R}$ & n \\
\hline Perception ratings & & \\
\hline Challenging and interesting work & 0.316 & 186 \\
\hline Feeling that a manager(s) takes personal interest in them & 0.342 & 187 \\
\hline Meaningful, timely, and constructive feedback & 0.311 & 186 \\
\hline Feeling that managers welcome their opinions and suggestions & 0.300 & 186 \\
\hline *Interpretation according to Dhuyvetter et al. ${ }^{4}$ & & Moderate \\
\hline
\end{tabular}

agement factors, grouped by low- or high-turnover ranch. Although overall importance ratings were similar, notable differences between low- and high-turnover ranch employees include "on-ranch work opportunities for family members" (3.11 low vs. 3.31 high), "recognition from a manager(s) for good work" (3.52 low vs. 3.65 high), "on-ranch recreational opportunities for family members" (3.23 low vs. 3.36 high), and "new employee training" (3.53 low vs. 3.39 high). These importance ratings indicate that employees on ranches with high turnover may desire more recognition and family involvement whereas employees on low-turnover ranches value more training.

The average perception rating for all employee management factors was 2.82 and 2.98 for employees at low- and high-turnover ranches, respectively. The lowest perception rating for both groups was for "new employee training." The greatest difference in average perception ratings between the two groups was for "meaningful, timely, and constructive feedback," and "feeling that managers welcome their opinions and suggestions," which employees at high-turnover ranches rated higher than employees at low-turnover ranches.

Overall, employee management gap rankings were very similar between the two turnover groups. The average gap for all employee management factors was 0.77 and 0.62 for employees on low- and high-turnover ranches, respectively. With exception of "on-ranch recreational opportunities for family members," which ranked as the lowest gap for both turnover groups, all employee management factor gaps were higher for low-turnover ranches. This is an interesting finding and could suggest that employees at ranches with low turnover have higher expectations of their general managers and the job itself than those on ranches with high turnover. Regardless of turnover, the largest gap for both groups was "new employee training," which further highlights the importance and need for a well-executed new employee training program on ranches.

\section{Correlations}

To quantify the effect of employee management practices, employee engagement, turnover rate, and labor cost per cow were collected as key metrics because they were hypothesized to be related to management practices.

Those survey items moderately correlated to employee engagement are listed in Table 4. Employee management factors that were moderately correlated with engagement include "challenging and interesting work," "feeling that a manager(s) takes personal interest in them," "meaningful, timely, and constructive feedback," and "feeling that managers welcome their opinions and suggestions." Previous research suggests engaged employees are attracted to, committed to, and fascinated by their work. ${ }^{9}$ Additionally, these results further support the importance of feedback to increase employee engagement. Businesses in the top quartile for employees saying "In the last six months, someone has talked to me about my progress" have $10-15 \%$ higher productivity than those in the bottom quartile..$^{10}$ These same authors listed the 12 elements that characterize engaged and productive employees, which also include "my supervisor seems to care about me" and "at work my opinions count."

Turnover was only found to be correlated with two factors in the general manager data set. Employee management gaps for "knowing and understanding the mission statement", and "feeling that criteria used to evaluate them accurately represents their job performance" were positively correlated to turnover. In addition to growth and development and the opportunity to share ideas, employees want clarity about an organization's mission, why they are important, and how they fit. ${ }^{9}$ Communicating an organization's mission or vision is important because vision guides culture. How well an employee fits a job and organization depends on how well they fit into the culture. A common reason for turnover within an organization is the employee not being a good cultural fit. Additionally, measuring performance based on the achievement of outcomes can be 


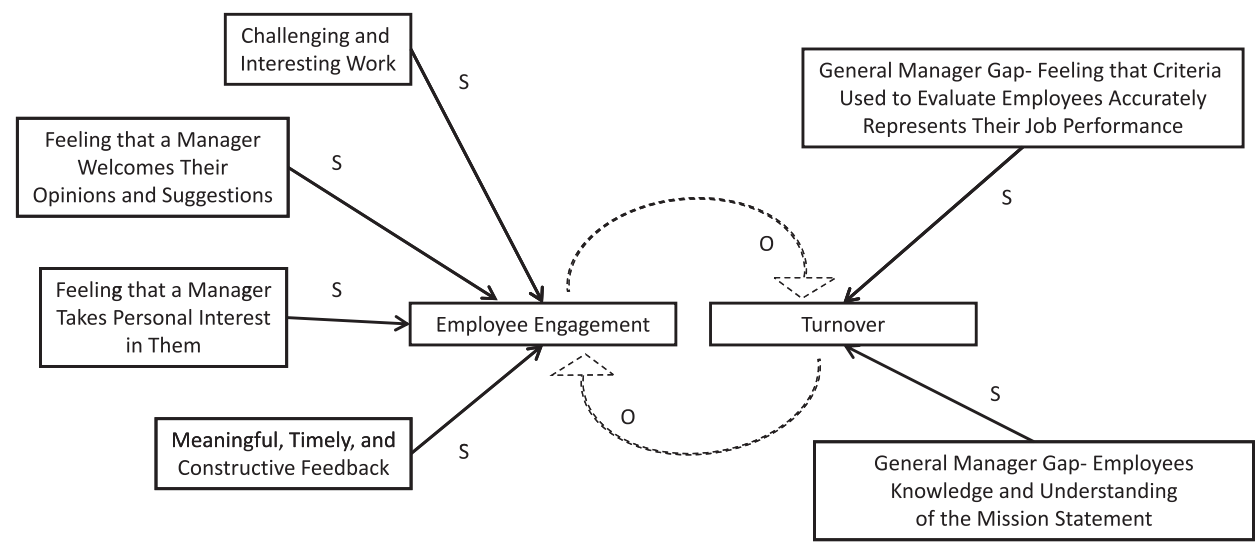

${ }^{a}$ A dashed line represents a theoretical relationship supported by literature and a solid line represents a correlation supported by this studies' data.

b $\mathrm{S}=$ There is a positive relationship between the two variables; $\mathrm{O}=$ There is an inverse relationship between the two variables.

Figure 3. Systems map of the theoretical relationship between turnover and engagement including factors statistically correlated to turnover and engagement.

an effective way to evaluate employees. However, this approach can be an unfair method of evaluation for businesses in complex and unpredictable environments such as ranching, where rewarding good decision-making can be a better way to recognize excellent employees. ${ }^{11}$ For instance, evaluating employees based upon weaning weights can be relevant during normal rainfall, but unfair during a drought. Yet, the ability to choose the correct evaluation metrics is only useful if those metrics are clearly communicated to employees. A significant cause of job dissatisfaction is the inability of employees to assess their own level of performance and success. ${ }^{12}$

Labor cost per cow was correlated with three factors in the general manager data set. Gaps for "recognition from a manager(s) for good work," "feeling that manager(s) take a personal interest in them," and "knowing and understanding the mission statement" were all negatively related to labor cost per cow. Based on the negative correlation between labor cost per cow and discrepancy scores for factors that require effort from a general manager (i.e., giving recognition, taking personal interest in employees, and ensuring they understand the mission statement), general managers might be viewing any effort to better communicate with employees as a cost in terms of time and energy, therefore raising expenses.

Turnover and labor costs per cow were not correlated. The cost of employee turnover can be substantial for a business, so we had hypothesized that a positive correlation between turnover and labor cost per cow may exist. Although this result will need to be further researched, the lack of relationship between the turnover and labor cost per cow in this study could be due to the fact that labor cost per cow can be kept low in the short term by limiting employee expenses, but might increase turnover in the long term.

Figure 3 illustrates the link between engagement and turnover, as well as factors statistically correlated to each of those two key metrics. Turnover was not correlated with employee engagement in our study, thus the dashed line connecting them represents a theoretical relationship only.

\section{Summary}

Managing people is a vital component of managing a large ranch. The shrinking number of people in the cattle industry elevates the importance of understanding of how to best manage and retain employees. Our study does not uncover specific strategic metrics for effective evaluation; however, it does indicate that no matter what metrics are chosen, making sure those metrics are clearly communicated is an important employee management practice. Including these metrics in a job description is one way to accomplish this. Employee management practices have an effect on turnover and employee engagement in any organization, and our study specifically examined management practices on ranches. Through practices that increase employees' understanding of the purpose of their job and how their performance is measured, such as new employee training, structured performance reviews, listening to their suggestions, and providing development opportunities, managers can positively impact employee engagement and turnover. Our study describes the state of employee management on large ranches and provides useful and practical information that may help ranch managers build their personnel management skills.

\section{References}

1. Borich, G. D. 1980. A needs assessment model for conducting follow-up studies. The Journal of Teacher Education 3(3):39-42.

2. PASW Statistics 18 [computer program]. 2009. Release 18.0.0. Chicago, IL, USA: SPSS, Inc.

3. Fernandez-Araoz, C., B. Groysberg, and N. Nohria. 2009. The definitive guide to recruiting in good times and bad. Harvard Business Review 87:74-84. 
4. Dhuyvetter, K. C., M. Langmeier, and S. Johnson. 2012. Beef cow-calf enterprise. Manhattan, KS, USA: Kansas State University Agricultural Experiment Station and Cooperative Extension Service. Farm Management Guide MF-266. Available at: http://www. ksre.ksu.edu/bookstore/pubs/mf266.pdf. Accessed 20 May 2012.

5. Gallup. 2011. Employee engagement; a leading indicator of financial performance. Available at: http://www.gallup.com/ consulting/52/employee-engagement.aspx. Accessed 3 March 2011.

6. Pink, D. H. 2009. Drive: the surprising truth about what motivates us. New York, NY, USA: Penguin-Riverhead. 272 p.

7. Barbuto, J. E., S. K. Trout, and L. L. Brown. 2004. Identifying sources of motivation of adult rural workers. Journal of Agricultural Education 45(3):11-21.

8. Harter, J. K., F. L. Schmidt, E. A. Killham, and S. AgrawAL. 2009. Q12 Meta-analysis: the relationship between engagement at work and organizational outcomes. Washington, DC, USA: The Gallup Organization. 44 p.
9. Seijts, G. H., and D. Crim. 2006. What engages employees the most or, the ten C's of employee engagement. Ivey Business Journal 2006(March/April):1-5.

10. Wagner, R., And J. K. Harter. 2006. 12: the elements of great managing. New York, NY, USA: Gallup Press. 237 p.

11. Ariely, D. 2010. Column: good decisions. Bad outcomes. Harvard Business Review 2010(December):28.

12. Lencioni, P. 2007. The three signs of a miserable job: a fable for managers and their employees. San Francisco, CA, USA: Jossey-Bass. 270 p.

Authors are Assistant Professor, ryan.rhoades@tamuk.edu (Rhoades), Graduate Assistant, (Livsey), Assistant Professor (McCuistion), and Director and Professor (Mathis), King Ranch Institute for Ranch Management, Texas AEऽM UniversityKingsville, Kingsville, TX 78363, USA. 